\title{
A Study On Temperature Changes In Thigh According To Diagnostic Ultrasonography Scan Time
}

\author{
Jiwon Kim, Hyunsoo Lim \\ Department of Biomedical Engineering, Chungnam University

\section{진단용 초음파 검사시간에 따른 허벅지의 온도 변화에 관한 고찰} \\ 김지원, 임현수 \\ 충남대학교 의공학과
}

\begin{abstract}
Effect of prenatal ultrasound diagnosis have serious damage for the possibility has been reported very low. Long time ultrasound scan can rise the temperature in body tissues and affect the physical. Changes in body temperature have been studied with ultrasound scan time. Fetal ultrasonography were evaluated without the influence of time. The findings, ultrasound scan time in 40 minutes the temperature was reduced. 50 minute tissue temperature rose more than $1{ }^{\circ} \mathrm{C}$. If within 40 minutes of ultrasound to be safe guess
\end{abstract}

Key Words : Ultrasonography Temperature Variation, Ultrasonography risk, Effect on fetal ultrasonography, Ultrasonography scan time

\section{요약}

진단적 초음파가 태아에 미치는 영향에 대하여는 대부분의 연구결과, 심각한 영향을 미칠 가능성이 매우 낮다고 보 고되고 있으나, 장시간의 과도한 조사는 초음파가 인체조직에 온도 상승이나 물리적인 영향을 줄 수 있어 초음파 검사 시간에 따라 허벅지의 온도 변화를 조사하여 태아 초음파 검사 시 영향이 없는 시간을 알아보았다. 그 결과 초음파 검 사 전보다 40 분 안에는 온도가 떨어졌고 50 분에는 허벅지의 온도가 검사 전보다 $1{ }^{\circ} \mathrm{C}$ 이상 올라가는 것을 확인하였다. 그러므로 40 분 안에 초음파 검사를 한다면 안전한 것으로 추론해 본다.

중심단어 : 초음파 온도변화, 초음파 위해성. 초음파 태아 영향. 초음파 검사시간

\section{I. 서론}

\section{1. 연구의 필요성 및 목적}

초음파 의료기기는 비 침습적이고 방사선검사와 달 리 전리 부작용이 없기 때문에 의료진단 및 치료에 널
리 사용되고 있다. 그러나 요즘 국제 초음파 협회 (World Federation for Ultrasound in Medicine and Biology, WFUMB), 미국 FDA, EU의 ECMUS (European Committee for the Medical Ultrasound Safety)등에서는 과도한 초음파 노출을 방지하기 위한 인식이 증가하 고 있으며 초음파기기의 음향출력에 대한 한계치를 
안과용 $17 \mathrm{~mW} / \mathrm{cm}^{2}$, 태아 또는 기타 $94 \mathrm{~mW} / \mathrm{cm}^{2}$, 심장 용 $430 \mathrm{~mW} / \mathrm{cm}^{2}$, 말초 혈관용 $720 \mathrm{~mW} / \mathrm{cm}^{2}$ 으로 제시 하였다 ${ }^{[1]}$

그리고 초음파가 인간의 생체조직에 영향을 미친다 는 것은 초음파 변환기 근처의 작은 물고기가 죽는 것 을 보고 알았다. 지난 27년 미국의 로버트 우드(Robert Wood) 등은 초음파가 생체조직에 미치는 영향을 조사 해 약 $300 \mathrm{kHz}$ 의 초음파를 수 분간 조사하였을 때 작은 물고기와 개구리들이 죽는 것을 관찰했다 ${ }^{[2]}$.

미국 예일대학 의과대학 신경생물학과장 파스코라 킥 박사는 국립과학원회보 (PNAS) 최신호에 발표한 연구논문에서 새끼를 밴 쥐들에 장시간 초음파를 조 사한 결과 뇌의 발달과정에서 신경원(신경세포)이 제 자리를 찾아 이동하는 것이 방해를 받는다는 사실을 밝혔다 ${ }^{[3]}$.

그럼에도 불구하고 우리나라 임산부들의 산전 초음 파 검사 횟수가 선진국에 비해 3 배 이상 높다. 미국 등 주요 선진국들은 산전 초음파 검사의 건강보험 적용 횟수를 1 3회로 제한해 특별한 경우가 아니면 3회를 넘지 않고 있다. 반면 우리나라의 경우 지난해 발표된 국민건강보험공단 통계를 보면, 임신부들의 초음파 검 사 횟수가 평균 10.7 회로 선진국에 비해 3 배 이상 높다 고 밝혀졌다. 진단용 초음파가 태아에 미치는 영향은 아직까지 확실하게 밝혀진 것은 없으나 장시간의 과 도한 검사는 초음파가 신체조직에 온도 상승이나 물 리적인 영향을 줄 수 있어 태아 초음파 검사가 완전히 무해하다고는 할 수 없다. 일부 연구에서는 출생 시 체중 감소나 성장기 언어발달 지연이 보고되어 태아 의 초음파 검사는 신중해야한다고 밝혔다.

식품의약품안전청은 의학적인 관점에서 보면 초음 파 영상 진단장치는 안전하며 태아에게 위해하다는 명백한 증거는 없지만, 초음파가 인체 조직에 물리적 영향을 끼치거나 온도상승이 발생할 수 있어 장기적 으로는 태아에게 악영향을 미칠 가능성을 배제 할 수 없고 반복적인 초음파 검사가 태아에 미치는 영향이 전혀 없다고 단정할 수 없어 진단 목적이 아닌 검사는 지양해야한다고 밝혔고 의학적으로 필요한 진단 검사 용 외에 다른 목적으로 이용되는 태아 초음파 촬영을 자제해 달라는 내용의 '의료기기 안전성 서한'을 대한
병원협회 등 관련 단체에 배포했다.

미국 식품의약국(FDA)도 이 같은 이유 때문에 2002 년부터 의료기관 외의 장소에서 진단 목적이 아닌 단 순한 기념 목적으로 태아의 성장단계별 초음파 검사 를 금지하고 있다 ${ }^{[4]}$.

이론적으로 볼 때 태아에 대한 초음파의 위험성은 열 효과이다. 이 점을 감안해 볼 때, 진단적 초음파가 태아에 미치는 영향에 대하여는 대부분의 연구결과, 심각한 영향을 미칠 가능성이 매우 낮다고 보고되고 있으나, 장시간 검사는 초음파가 신체조직에 온도 상 승을 일으킬 수 있어 초음파 검사 시간에 따라 연부조 직의 온도 증가 변화를 조사하여 태아 초음파 검사 시 영향이 없는 시간을 아는 것은 의미 있는 일이라 생각 되어 본 연구를 하게 되었다.

\section{T. 연구대상 및 방법}

\section{1. 연구 대상}

본 연구의 실험 대상은 감기 고열 등 인체 온도에 영향을 줄 수 있는 질환의 병력이 없고 건강한 가임 여성 30 명을 대상으로 하였다. 피검자의 신체적 특성 은 다음과 같다 (Table 1).

(Table 1) Physical characteristics

\begin{tabular}{ccccc}
\hline \hline & 나이 & 체중 $(\mathrm{kg})$ & 신장 $(\mathrm{cm})$ & 이마온도 $\left({ }^{\circ} \mathrm{C}\right)$ \\
\hline $\mathrm{N}=30$ & 29.03 & 53.89 & 161.61 & 36.57 \\
\hline \hline
\end{tabular}

\section{2. 연구 방법}

실험 전 신장체중계를 사용하여 피험자의 체중과 신장 등을 측정하였다. 각 실험대상자들은 실험 시작 30 분전에 실험실에 도착하여 이마 온도를 측정하여 고 열이 있는지 검사하였다.

실험 시작 전에 양쪽 허벅지 온도를 측정하고 한쪽 허벅지에 초음파를 조사하여 10 분 후, 20 분 후, 30 분 후, 40 분 후, 50 분 후 검사 시간 따라 허벅지 온도를 측 정 하고 실내온도 및 신체 변화에 의한 온도 영향과 
적외선 인체 온도 측정기에 의한 오차가 없다는 것을 증명하기 위해 다른 한쪽 허벅지에도 초음파를 조사 하지 않고 10 분 후, 20 분 후, 30 분 후, 40 분 후, 50 분 후 에 허벅지 온도를 측정하였다. 초음파 투과력을 좋게 하기 위해 젤을 사용하고 실내온도를 $26 \sim 28^{\circ} \mathrm{C}$ 로 유지 하였다.

\section{3. 실험기기}

\section{1) 초음파}

초음파 기기는 미국 GE사의 logic book Portable 장 비로 부채꼴형 탐촉자(Convex probe)를 이용하여 주파 수 $4 \mathrm{MHz}$, 출력 $100 \%$, 깊이 $16 \mathrm{~cm}$ 으로 설정 하였다.

\section{2) 적외선 인체 온도 측정기}

(Table 2) Infrared body temperature measurement

\begin{tabular}{c|c}
\hline \hline 측정모드 & 비접촉식 적외선측정 \\
제조사 & 마스텍 \\
모델명 & MS6530C \\
측정범위 & $28 \sim 42{ }^{\circ} \mathrm{C}$ \\
분해능 & $0.1{ }^{\circ} \mathrm{C}$ \\
정확도 & $\pm 0.4{ }^{\circ} \mathrm{C}$ \\
응답시간 & 1 초이내 \\
작동온도 & $-10{ }^{\circ} \mathrm{C} \sim 35^{\circ} \mathrm{C}$ \\
측정거리 & $200 \mathrm{~mm}$ 이내 \\
설정 & 최대값, 최소값, 최대-최소값, 평균값 선택가능 \\
온도표시 & 섭씨 $/$ 화씨 표시 가능 \\
알람기본 온도 & $37.5^{\circ} \mathrm{C}$ (작동온도 $25^{\circ} \mathrm{C}:$ 측정거리 $20 \mathrm{~cm}$ 이내 \\
피부선택기능 & 0 - white, $1-y e l$ low, $2-b l a c k$ \\
\hline \hline
\end{tabular}

\section{4. 자료처리 및 통계분석}

수집된 자료의 통계분석은 SPSS(ver12.0)을 이용하여 처리하였고, 조사 대상자의 신체적 특성은 T-test, 초음 파 검사 시 온도 변화는 대응표본 $\mathrm{T}$ 검정(paired $\mathrm{T}$-test) 과 독립표본 $\mathrm{T}$ 검정(independent $\mathrm{T}$ test)을 사용 하였으 며 모든 통계량의 유의 수준은 $\mathrm{P}<0.05$ 로 하였다.

\section{III. 연구결과}

\section{1. 결과 1}

초음파를 조사한 연부조직과 초음파를 조사하지 않 은 연부조직의 시간별 온도변화는 table 3 과 같다. 시간 은 초음파 조사 전, 10 분 후, 20 분 후, 30 분 후, 40 분 후, 50 분 후 6단계로 나뉘며 각 시간별 평균값과 표준편차 값은 초음파를 조사한 경우 조사 전 $34.64 \pm 1.32,10$ 분 후 $30.59 \pm 2.20,20$ 분 후 $30.87 \pm 2.21,30$ 분 후 $32.29 \pm 1.76$, 40 분 후 $34.55 \pm 1.45,50$ 분후 $35.78 \pm 1.38$ 로 50 분 후의 평 균값이 가장 높았으며 10 분후 온도가 가장 낮음을 알 수 있다. 초음파를 조사하지 않은 경우에는 조사 전 $34.85 \pm 1.41,10$ 분후 $34.85 \pm 1.44,20$ 분후 $34.85 \pm 1.42,30$ 분 후 $34.84 \pm 1.41,40$ 분후 $34.85 \pm 1.43,50$ 분후 $34.85 \pm 1.42$ 로 온도가 거의 비슷했다.

평균과 표준편차로 알아본 차이가 통계적으로 유의 한 차이를 가지는지 알기 힘들기 때문에 초음파 조

(Table 3) Change in thigh temperature of ultrasound scan and no ultrasound scan with times

\begin{tabular}{|c|c|c|c|c|}
\hline Classification & Time & Temperature & T-value & P-value \\
\hline \multirow{6}{*}{ Ultra Sound scan } & pre.US & $34.64 \pm 1.32$ & -0.596 & 0.553 \\
\hline & 10min & $30.59 \pm 2.20$ & -8.877 & 0.000 \\
\hline & 20min & $30.87 \pm 2.21$ & -8.313 & 0.000 \\
\hline & 30min & $32.29 \pm 1.76$ & -6.185 & 0.000 \\
\hline & 40min & $34.55 \pm 1.45$ & -0.815 & 0.418 \\
\hline & $50 \mathrm{~min}$ & $35.78 \pm 1.38$ & 2.577 & 0.013 \\
\hline \multirow{6}{*}{$\begin{array}{c}\text { NOT } \\
\text { Ul tra Sound scan }\end{array}$} & pre.US & $34.85 \pm 1.41$ & -0.596 & 0.553 \\
\hline & $10 \mathrm{~min}$ & $34.85 \pm 1.44$ & -8.877 & 0.000 \\
\hline & 20min & $34.85 \pm 1.42$ & -8.313 & 0.000 \\
\hline & 30min & $34.84 \pm 1.41$ & -6.185 & 0.000 \\
\hline & 40min & $34.85 \pm 1.43$ & -0.815 & 0.418 \\
\hline & $50 \mathrm{~min}$ & $34.85 \pm 1.42$ & 2.577 & 0.013 \\
\hline
\end{tabular}


(Table 4) Change in thigh temperature of ultrasound scan compared to baseline

\begin{tabular}{cccc}
\hline \hline Time interval & Temperature & T-value & P-value \\
\hline pre.Ultra Sound - 10min & $-4.05 \pm 1.24$ & -17.867 & 0.000 \\
pre.Ultra Sound - 20min & $-3.77 \pm 1.30$ & -15.811 & 0.000 \\
pre.Ultra Sound - 30min & $-2.35 \pm 1.06$ & -12.165 & 0.000 \\
pre.Ultra Sound $-40 \mathrm{~min}$ & $-0.09 \pm 0.72$ & -0.683 & 0.500 \\
pre.Ultra Sound $-50 \mathrm{~min}$ & $1.14 \pm 0.56$ & 11.183 & 0.000 \\
\hline \hline
\end{tabular}

사 시간별 온도 변화에 대한 독립표본 T검정 (independent t-test)을 실시하였다. 그 결과는 초음파를 조사한 경우 조사 전 $-0.596,10$ 분 후 $-8.877,20$ 분 후 $-8.313,30$ 분 후 $-6.185,40$ 분 후 $-0.815,50$ 분 후 2.577 로 나타났다. 초음파를 조사하지 않은 경우에는 조사 전 $-0.596,10$ 분 후 $-8.877,20$ 분 후 $-8.313,30$ 분 후 $-6.185,40$ 분 후 $-0.815,50$ 분 후 2.577 로 나타났다. 이에 따른 유의 확률 값은 모두 유의 수준 0.05 에서 유의한 결과를 나타내었다. 즉 이 말은 초음파 조사 후 시간 별 온도가 다르며 50 분 후 온도가 가장 높았고 10 분 후 온도가 가장 낮음을 알 수 있다(Table 3).

\section{2. 결과 2}

초음파 조사 전과 비교하여 초음파 조사 후 시간에 따른 온도변화는 table 4 와 같다. 시간은 10 분 후, 20 분 후, 30 분 후, 40 분 후, 50 분 후 5 단계로 나뉘며 각 시간 별 평균값과 표준편차 값은 10 분 후 $-4.05 \pm 1.24,20$ 분 후 $-3.77 \pm 1.30,30$ 분 후 $-2.35 \pm 1.06,40$ 분 후 $-0.09 \pm 0.72$, 50 분 후 $1.14 \pm 0.56$ 으로 검사 전보다 10 분에서 40 분 사 이에는 검사전보다 평균값이 떨어졌으나 50 분 후에 평 균값이 높아졌다.

평균과 표준편차로 알아본 차이가 통계적으로 유의 미한 차이를 가지는지 알기 힘들기 때문에 초음파 조 사 전과 비교하여 초음파 조사 후 시간에 따른 온도변 화 대한 대응표본 $\mathrm{T}$ 검정(paired $\mathrm{T}$ test)을 실시하였다. 그 결과는 10 분후 $-17.867,20$ 분후 $-15.811,30$ 분후 $-12.165,40$ 분후 $-0.683,50$ 분후 11.183 로 나타났다. (Table 4).

\section{$\mathrm{IV}$. 고 찰}

현재까지는 국내에서 진단용 초음파에 의한 피해 사례는 뚜렷이 나타나고 있지 않다. 그러나 초음파도 에너지의 일종이며 높은 용량을 장시간 조사하면 상 당한 열을 조직 안에서 발생시킬 수 있어 사람에서 사 용하는 것보다 고용량의 초음파를 사용한 일부 임신 동물 실험에서는 새끼에서 기형이 생기는 것으로 나 왔다. 그러한 동물 실험의 결과가 사람에서도 똑같이 적용된다고 단언할 수는 없지만 동물 실험의 결과가 사람에서 그대로 적용되는 것은 아니라도 무시할 수 는 없다 ${ }^{[5]}$.

Evans와 Michael은 오스트레일리아에서 18주에서 38 주 사이 1400 명의 임신한 여성에서 임신 기간 동안 매 달 초음파 검사를 한 그룹과 한번만 초음파 검사를 한 그룹을 비교한 결과 매달 초음파 검사를 한 그룹에서 는 상당히 높은 자궁 내 성장 제한을 발견 했고 이들 은 저체중의 아이를 출산하였다 ${ }^{[6]}$.

Campbell과 Elford는 2세에서 8세사이의 72 명의 어 린이를 대상으로 초음파에 노출된 그룹과 초음파에 노출되지 않은 그룹을 비교한 결과 초음파에 노출된 그룹에서는 언어를 배우는 것이 2 배 느리다는 연구결 과를 발표했다 ${ }^{[7]}$.

Devi과 Suresh, Hande는 임신한 쥐를 초음파에 노출 된 그룹과 초음파에 노출되지 않은 그룹을 비교한 결 과 초음파에 노출된 그룹의 쥐에서는 운동능력과 이 동능력이 감소되었다 ${ }^{[8]}$.

미국 예일대학 의과대학 신경생물학과장 파스코라 킥 박사는 새끼를 밴 쥐들에 장시간 초음파를 조사한 결과 최저 5 분에서 최고 420 분까지 초음파를 조사하고 태어난 새끼들의 뇌를 검사한 결과 초음파 조사 시간 이 총 30 분 이상인 경우 적지만 통계상 상당한 의미를 갖는 수의 신경세포들이 제 자리를 찾아가지 못하고 뇌의 엉뚱한 자리에서 흩어진 상태로 있었으며 제 자 리로 이동하지 못한 신경세포의 수는 조사 시간이 길 수록 더 많았다 ${ }^{[9]}$.

이러한 결과는 초기 태아 기간 동안 초음파 노출은 성인 쥐의 뇌 기능에 악영향을 줄 수 있음을 나타냈다. 
이 처럼 많은 연구 논문에서 태아 초음파 검사의 유 해성에 대해 주장 하고 있지만, 초음파의 생물학적 효 과와 잠재적인 유해성에 관해서는 관심이 부족한 것 이 사실이다.

많은 연구 결과에 의하면 인체 조직은 짧은 시간 동 안에 $1{ }^{\circ} \mathrm{C}$ 의 작은 온도 변화에도 상당히 민감한 반응을 나타내는 것으로 보고되고 있다 ${ }^{[10]}$.

일반적으로 태아의 체온은 모체의 중심온도 보다 $0.3 \sim 0.5^{\circ} \mathrm{C}$ 정도 높다. 그리고 고열은 세포분열을 멈추게 하고 때로는 분열되고 있는 세포를 파괴시킬 수 있다. 따라서 모체의 복부의 온도 상승은 가끔씩 태아의 뇌 발달상 크기와 기능에 심각한 문제를 일으키기도 한 다 ${ }^{[11]}$.

신동욱 등 초음파 흡수에 의한 단백질에서의 온도 변화 특성 연구에서는 초음파 조사 시 발생되는 온도 변화 특성은 시간에 대해 $\log$ 형태를 나타내며, 열확산 에 의해 초기에 급격한 온도 증가를 나타냈다. $10 \mathrm{MHz}$ 의 집속형 초음파 변환기 초점에서 강도가 $13.3 \mathrm{~W} / \mathrm{cm}^{2}$ 인 초음파를 계란 흰자에 조사하였을 때 5 분후에 온도 증가가 $1.5^{\circ} \mathrm{C}$ 이상으로 나타났다 ${ }^{[12]}$.

본 연구는 태아의 안전성 때문에 산모를 대상으로 온도를 측정하지 못했다. 그리고 가임기 여성으로 난 소에 영향을 미칠 수 있기 때문에 복부온도를 측정하 지 못하고 복부와 가장 비슷한 연부조직이 많은 허벅 지 온도를 측정하여 초음파 조사시 허벅지 연부조직 의 온도가 올라간다면 복부의 연부조직도 올라갈 것 이라는 가정 하에 연구를 하여 태아 초음파 검사 시 안전한 노출시간 기준을 위한 토대를 마련 하고자 하 였다.

선행 연구와의 차이점은 일반 산부인과에서 태아를 검사하는 조건과 비슷하게 탐촉자의 주파수와 초음파 강도를 설정하고 허벅지의 연부조직을 사용하여 실험 을 하였다.

실험대상이 사람을 대상으로 하였기 때문에 연구윤 리 의식에 의해 실험자에게 충분히 설명을 하고 동의 를 얻었다.

연구 결과 진단용 초음파 조사 후 40 분 안에는 오히 려 검사 전보다 허벅지의 온도가 떨어졌는데 이것은
젤의 온도와 혈류의 흐름으로 인하여 냉각(Cooling)되 기 때문으로 사료 된다. 초음파 조사 후 50 분에는 허벅 지의 온도가 초음파 조사 전보다 $1{ }^{\circ} \mathrm{C}$ 이상 올라가는 것 을 볼 때 초음파 조사 시 40 분 전까지는 인체에 영향 이 없다고 사료 된다

현재 태아 초음파 검사는 태아 성장 과정과 기형아 진단에 필수적 검사인데도 불구하고 초음파의 생물학 적 효과와 잠재적인 유해성에 관한 연구가 부족한 실 정이다. 산전 검사에서의 초음파의 이론적 유해성은 열 효과가 태아에게 줄 수 있는 위험성으로 고온의 환 경이 태아에게 미칠 수 있는 영향이 동물 실험에서 입 증되어 인간에게도 그 가능성이 제기되었으나, 현재까 지 진단적 목적의 초음파검사가 인간 태아에게 기형 이나 유산을 일으키거나 출생 후 신경발달장애를 유 발했다는 보고도 없다.

그러나 상당수의 연구들은 절대적으로 완벽하다고 는 할 수 없다. 그 이유는 대부분 초음파 검사가 인체 나 태아에 쓰인 지는 오래되지 않았기 때문에 오랫동 안에 걸친 문제점들은 아직 깊이 연구되지 못했다.

이러한 문제점을 해결하려면 성인에서 또는 임신 중 태아 검사를 위하여 시행한 많은 사람을 대상으로 연구가 되어야한다. 완벽한 연구가 되려면 같은 조건 에 있는 산모에서 태어난 태아를 대상으로 초음 파검 사를 받은 사람과 받지 않은 사람을 구분하여 비교해 야하고, 이에 더해서 초음파 검사를 받은 임신 주수와 시간, 사용한 초음파 기계 종류와 그 특성 등에 대하 여서도 미리 확인되어야 하므로 이러한 연구를 하는 것은 대단히 어렵다.

또한, 모태에서부터 초음파의 영향을 받고 태어난 아이가 성장하는 과정에서의 문제점은 없는지 연구해 야한다. 그리고 태아 난소나 태아 고환도 초음파의 영 향을 받을 수 있기 때문에 이들이 커서 임신했을 때 태아에 미치는 영향은 없는지 까지 연구해야한다.

또한, 외국의 가이드라인처럼 무작위 대조 임상 실험과 체계적 문헌고찰을 통해 임신기간에 따라 적절하고 근거 있는 초음파 진단의 목적과 횟수 및 방법을 제시하고, 이 러한 기본적인 산전 초음파 진단에 대해서는 건강보험 급 여를 적용하여 과잉지료 및 검사를 줄이는 동시에 출산 장려를 위한 제도개선 방안 중의 하나로 시행해야 한다. 


\section{V. 결론}

본 연구는 진단용 초음파 검사시간에 따른 허벅지 의 온도변화를 조사하여 태아 초음파검사 시 영향이 없는 시간을 알아보고자 하였다.

가임기 여성 30 명을 대상으로 초음파 검사 시간에 따른 허벅지의 온도변화를 측정해본 결과 다음과 같 은 결과를 얻었다.

첫째, 진단용 초음파 조사 후 40 분 안에는 오히려 검사 전보다 온도가 떨어졌다.

둘째, 50 분에는 검사전보다 $1{ }^{\circ} \mathrm{C}$ 이상 증가했다.

본 연구의 결과를 종합해 보면 초음파 검사 전의 체 온보다 검사 시작하여 40 분 이내에는 온도가 떨어졌고 50 분에는 허벅지의 온도가 검사 전보다 $1{ }^{\circ} \mathrm{C}$ 이상 올라 가는 것을 볼 때 40 분 이내에 초음파 검사를 한다면 안전한 것으로 추론해 본다.

따라서 산전 진단에 있어 초음파검사의 유용성을 고려한다면 이론적인 위험성 때문에 의학적인 목적의 초음파 검사를 제한할 필요는 없으나 진단초음파에서 ALARA (As Low As Reasonably Achievable)의 원리를 적용하기 위해 오직 의학적으로 타당한 경우에만 사 용해야하고 가능한 힘(Power)을 줄이고 게인(gain)을 높 여서 사용해야한다. 또한 조사시간을 줄이고 Doppler 는 신중하게 사용해야한다.

그리고 숙련된 검사자에 의해 초음파 검사시간을 최소한으로 해야 하고 또한 산전 초음파검사를 시행 하는 검사자는 초음파의 생물학적 효과에 대해 숙지 하고 있어야하며 검사에 대한 지식과 숙련도를 향상 시키도록 끊임없이 노력해야한다.

\section{참고 문헌}

[1] Merrit CR, Kremkau FW,Hobbins JC. Diagnostic ultrasound: bioeffects and safety. Ultrasound Obstet Gynecol Vol. 166, pp.366-374, 1992.

[2] Lyons EA, Dyke C, Toms M, Cheang M. In utero exposure to diagnostic ultrasound: a 6-year follow-up. Radiology Vol. 12, pp.166-687, 1988.

[3] Nicolaides KH, Azar G, Byrne D, Mansur C, Marks K. Fetal nuchal translucency : ultrasound screening for chromosomal defects in first trimester of pregnancy. BMJ Vol. 93, pp.867-869, 1992.

[4] Benacerraf BR. Three-dimensional fetal sonography : use and misuse. J Ultrasound Med Vol. 21, pp.1063-1067, 2002.

[5] Church CC, Miller MW. Quantification of risk from fetal exposure to diagnostic. Prog Biophys Mol Biol : Vol. 93, pp.331-353, 2007.

[6] Newnham, J.P., Evans, S.F., Michael, C.A., Stanley, F.J., \&Landau, L. I. Effects of Frequent Ultrasound During Pregnancy: A Randomized Controlled Trial. The Lancet, Vol. 342, pp.1435-1440, 1993.

[7] Campbell, J.D., Elford, R.W. \&Brant, R.F Case-Controlled Study of Prenatal Ultrasound Exposure in Children with Delayed Speech. Canadian Medical Association Journal, Vol. 149, No. 10, pp.1435-1440, 1993.

[8] Devi, P.U., Suresh, R., \&Hande, M.P. Effect of fetal exposure to ultrasound on the behavior of the adult mouse. Radiat Res (QMP), Vol. 141, No. 3, pp.314-7, or pp.314-320, 1995.

[9] Zhu J, Lin j, Zhu Z, Shou W, Bi D, Shi L. Effects of doagnostic levels of color Doppler ultrasound energy on the cell cycle of newborn rats. J Ulrasound Med Vol. 18, pp.257-2601, 1999.

[10] C.M.Schgal, J.F. Greemleaf, "Ultrasonic absorption and dispersion in biological media : A postulated model" J.Acoust.Soc.Am. Vol. 72, No. 6, pp.1711-1718, 1982.

[11] R.M.Arther, K.V.Gurumurthy. " A single-pole model for the propagation of ultrasound in soft tissue" J.Acoust.Soc.Am. Vol. 77, No. 4, pp.1589-1597, 1985.

[12] 신동묵 : 초음파 흡수에 의한 단백질에서의 온도 변화 특성, pp.162, 1993. 